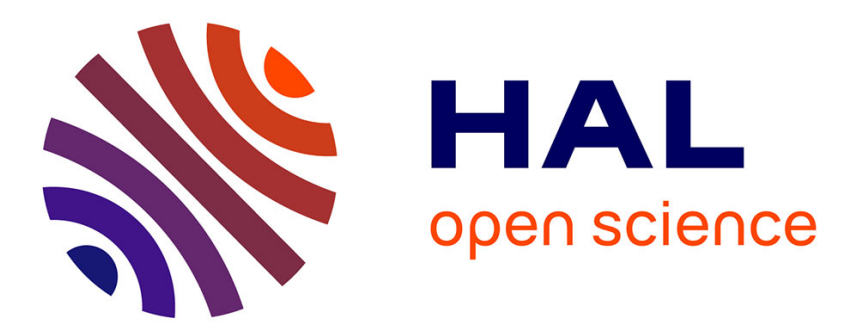

\title{
Earthworm effects on plant growth do not necessarily decrease with soil fertility
}

Kam-Rigne Laossi, Amandine Ginot, Diana Noguera, Manuel Blouin, Sébastien Barot

\section{- To cite this version:}

Kam-Rigne Laossi, Amandine Ginot, Diana Noguera, Manuel Blouin, Sébastien Barot. Earthworm effects on plant growth do not necessarily decrease with soil fertility. Plant and Soil, 2009, 328, pp.109 - 118. 10.1007/s11104-009-0086-y . bioemco-00574553

\section{HAL Id: bioemco-00574553 https://hal-bioemco.ccsd.cnrs.fr/bioemco-00574553}

Submitted on 8 Mar 2011

HAL is a multi-disciplinary open access archive for the deposit and dissemination of scientific research documents, whether they are published or not. The documents may come from teaching and research institutions in France or abroad, or from public or private research centers.
L'archive ouverte pluridisciplinaire HAL, est destinée au dépôt et à la diffusion de documents scientifiques de niveau recherche, publiés ou non, émanant des établissements d'enseignement et de recherche français ou étrangers, des laboratoires publics ou privés. 


\title{
Earthworm effects on plant growth do not necessarily decrease with soil fertility
}

\author{
Kam-Rigne Laossi • Amandine Ginot • \\ Diana Cristina Noguera • Manuel Blouin • \\ Sébastien Barot
}

Received: 2 February 2009 /Accepted: 22 June 2009 /Published online: 30 June 2009

(C) Springer Science + Business Media B.V. 2009

\begin{abstract}
Earthworms are known to generally increase plant growth. However, because plant-earthworm interactions are potentially mediated by soil characteristics the response of plants to earthworms should depend on the soil type. In a greenhouse microcosm experiment, the responsiveness of plants (Veronica persica, Trifolium dubium and Poa апnиa) to two earthworm species (in combination or not) belonging to different functional groups (Aporrectodea. caliginosa an endogeic species, Lumbricus terrestris an anecic species) was measured in term of biomass accumulation. This responsiveness was compared in two soils (nutrient rich and nutrient poor) and two mineral fertilization treatments (with and without). The main significant effects on plant growth
\end{abstract}

Responsible Editor: Wim van der Putten.

K.-R. Laossi $(\bowtie) \cdot$ A. Ginot $\cdot$ D. C. Noguera $\cdot$ S. Barot

Bioemco (UMR 7618)/Université Pierre et

Marie Curie-IBIOS,

Centre IRD d'Ile de France 32, avenue Henri Varagnat,

93140 Bondy Cedex, France

e-mail: kam-rigne.laossi@bondy.ird.fr

M. Blouin

Bioemco (UMR 7618)—IBIOS/Université Paris 12,

61 avenue du Général De gaulle,

94010 Créteil Cedex, France

S. Barot

IRD_Bioemco (UMR 7618), Ecole Normale Supérieure,

46 rue d'Ulm,

75230 Paris cedex 05, France were due to the anecic earthworm species. L. terrestris increased the shoot biomass and the total biomass of $T$. dubium only in the rich soil. It increased also the total biomass of $P$. апnua without mineral fertilization but had the opposite effect with fertilization. Mineral fertilization, in the presence of $L$. terrestris, also reduced the total biomass of $V$. persica. L. terrestris did not only affect plant growth. In $P$. апnиa and $V$. persica A. caliginosa and $L$. terrestris also affected the shoot/root ratio and this effect depended on soil type. Finally, few significant interactions were found between the anecic and the endogeic earthworms and these interactions did not depend on the soil type. A general idea would be that earthworms mostly increase plant growth through the enhancement of mineralization and that earthworm effects should decrease in nutrient-rich soils or with mineral fertilization. However, our results show that this view does not hold and that other mechanisms are influential.

Keywords Earthworms $\cdot L$. terrestris $\cdot$ A. caliginosa Plant growth · Soil type $\cdot$ Nutrient availability Shoot/root ratio

\section{Introduction}

Soil organisms are known to affect plant growth by enhancing mineralisation of soil organic matter and modifying physical and chemical properties of soil 
(Bardgett et al. 2005; Lavelle and Spain 2001). Within soil organisms, earthworms are in term of biomass and activity among the most important detritivores in terrestrial ecosystems (Edwards 2004). They are also known to affect plant growth, generally positively, via five main mechanisms (Brown et al. 2004; Scheu 2003): (1) an increased mineralization of soil organic matter (2) the production of plant growth substances via the stimulation of microbial activity; (3) the control of pests and parasites; (4) the stimulation of symbionts and (5) modifications of soil porosity and aggregation, which induces changes in water and oxygen availability to plant roots. Although these mechanisms are well identified it is difficult to determine their relative influence (Blouin et al. 2006) either in precise cases or in broad classes of cases as defined by plant functional type, geographic area or soil type.

Brown et al. (2004) has remarked that the response of plants to earthworms should depend on the type of soil and especially its texture and its richness in mineral nutrients and organic matter. Indeed, mechanisms through which earthworms influence plant growth might be either down or up-regulated by soil characteristics. For example, if the positive effect of an earthworm species on plant growth is mainly due to an increase in mineralization, the species might no longer increase plant growth in a soil where nutrients are not limiting. However, few studies (Doube et al. 1997; Wurst and Jones 2003) have tested the effect of earthworms on plant in different soils in the same laboratory experiment. Doube et al. (1997) have shown that Aporrectodea trapezoides increased the growth of wheat in a sandy soil but not in a clayey one. They also showed that the growth and the grain yield of barley were increased by Aporrectodea trapezoides and Aporrectodea rosea (both are endogeic earthworms) in the sandy soil but reduced in the clayey. On the contrary, Wurst and Jones (2003) have shown that Aporrectodea caliginosa increased the root biomass of Cardamine hirsute in two different soils. Up to our knowledge, no laboratory experiment has so far compared the effect of two earthworm species belonging to different functional groups on the same plant species, in soils differing by their texture and nutrient content. Our experiment aims at meeting this need.

Besides, plant species of different functional groups should respond differently to earthworms
(Brown et al. 2004) because they are not limited by the same resources and do not have the same resource allocation strategies (Laossi et al. 2009). Legumes, for example, are thought to be less responsive to earthworms than grasses since they are not limited by nitrogen (Brown et al. 2004; Wurst et al. 2005). Finally, plant responses may also depend on earthworm functional group since earthworm belonging to different functional groups differ in their behaviors (Lavelle and Spain 2001). For example, endogeic earthworms keep moving inside the soil to feed on soil organic matter while anecic feed on plant litter at the soil surface and tend to stay in the same burrow (Lavelle et al. 1998). Anecic earthworms fragment plant litter and incorporate it into the soil where it can subsequently be ingested by endogeic earthworms. Such an interaction could increase further mineralization and plant growth (Brown et al. 2000; Jégou et al. 1998).

We tested how the effects of earthworms belonging to different functional groups on plant growth covary with plant functional group and soil type. Hence, we investigated in a microcosm greenhouse experiment the responsiveness of three annual plant species of different functional groups (Роа апnиа, a grass; Trifolium dubium, a legume; Veronica persica, a forb) to an endogeic (Aporrectodea caliginosa) and anecic (Lumbricus terrestris) earthworm species as well as to the combination of the two species. The responsiveness of plant was measured in term of biomass accumulation and was compared in two soils (a clayey nutrient rich soil with higher organic matter content and a sandy nutrient poor soil with lower organic matter content) and two mineral fertilization treatments (with and without). Mineral fertilization can be considered either to mimic richer soils or agricultural practices.

We hypothesized that earthworms affected plant growth mainly through an enhancement of mineralization, which is the more often cited mechanism (Kreuzer et al. 2004; Partsch et al. 2006; Wurst et al. 2003). Therefore (see above), both earthworm species should affect (1) plant growth and (2) plant resource allocation only in the soil that is poor in organic matter and mineral nutrient. Similarly, (3) significant interactive effects of the two earthworm species on plant growth and resource allocation should only be found in the poor soil. Finally, according to the same assumption that earthworm mostly influence plants by increasing the availability of mineral nutrients, (4) the 
impact of $A$. caliginosa and $L$. terrestris on plants should decrease with mineral fertilization.

\section{Materials and methods}

\section{Experiment set up}

The experiment was set up in microcosms consisting of PVC pots (inner diameter $14 \mathrm{~cm}$, height $12.5 \mathrm{~cm}$ ) that were closed at the bottom with $1 \mathrm{~mm}$ plastic mesh to prevent earthworms from escaping. A total of 320 microcosms were filled with $950 \mathrm{~g}( \pm 20 \mathrm{~g})$ of sieved $(2 \mathrm{~mm})$ dry soil in a greenhouse. Before starting our experiment, the microcosms were watered regularly for 2 weeks and germinating weeds from the seedbank were removed. Eight grams of dried litter $\left(72 \mathrm{~h}\right.$ at $\left.60^{\circ} \mathrm{C}\right)$ of grass leaves were placed at the soil surface and $1 \mathrm{~g}$ was mixed with the first $\mathrm{cm}$ of soil, prior to the addition of earthworms and seeds. This constituted the essential food resource for the anecic earthworm species.

\section{Soils}

We used two different soils: A sandy cambisol (called hereafter in the text the "nutrient poor soil") supporting a meadow $(\mathrm{OM}=2.55 \% ; \mathrm{C} / \mathrm{N}$ ratio $=12.4$; total carbon content $=1.47 \%$; Ntotal $=0.12 \% ; \mathrm{pH}=5.22$ ) collected at the ecology station of the Ecole Normale Supérieure at Foljuif (France) and a clayey leptosol $(\mathrm{OM}=9.81 \% ; \mathrm{C} / \mathrm{N}$ ratio $=12.2$; total carbon content $=$ $5,67 ;$ Ntotal $=0.465 ; \mathrm{pH}=7.45)$ collected at the ecology station of Brunoy (France) (called hereafter the "nutrient rich soil").

\section{Earthworms}

We used an anecic earthworm, Lumbricus terrestris (L.) -LT-, and an endogeic earthworm, Aporrectodea caliginosa (Savigny) -AC-. LT were purchased in a store and $\mathrm{AC}$ were collected in the park of the IRD centre in Bondy (France). Our experiment consisted in four treatments: $\mathrm{AC}, \mathrm{LT}, \mathrm{AC}+\mathrm{LT}$ and a control without any earthworm species (C). One adult of LT $(4.2 \pm 0.5 \mathrm{~g})$ and three adults of AC $(2.4 \pm 0.4 \mathrm{~g})$ were introduced in each treatment including these species. This represents respectively $273 \mathrm{~g} \mathrm{~m}^{-2}$ and $156 \mathrm{~g} \mathrm{~m}^{-2}$, which is comparable to the biomasses found in temperate grassland ecosystems (Edwards and Bohlen
1996). In the treatment with both earthworm species $(\mathrm{AC}+\mathrm{LT})$ we have maintained for each earthworm species the biomass used in AC and LT treatment. This was done to maintain the same activity level of each earthworm species, which was the only way to allow testing for a possible interactive effect of the two earthworm species on plant growth. $96 \%$ of the earthworms were recovered at the end of the experiment (471 A. caliginosa and 143 L. terrestris individuals among the 480 and 160 that were originally introduced respectively).

Plants

One week after introducing earthworms, 15 seeds of Veronica persica, Trifolium dubium and Poa annua were sown in monocultures. Three weeks later, a single plant per microcosm was kept (the other seedlings were removed and cut down in the original microcosm). Microcosms were weeded every week during the experiment. Microcosms were watered during 7 weeks with $6.5 \mathrm{ml}$ every day and from 8th week to the end (week 16) with $13 \mathrm{ml}$ every day. This allowed us to maintain the soil near its field capacity (this was checked through regular weighing of some pots). Microcosm position within the greenhouse was randomized every 2 weeks.

\section{Fertilizer}

For each combination of treatments (soil type $\times$ LT $\times$ $\mathrm{AC} \times$ plant species), two fertilization treatments were implemented: without or with mineral fertilization. This treatment consists in an application of fertilizer containing $\mathrm{N}, \mathrm{P}, \mathrm{K}, \mathrm{S}$ and Mg. $0.6 \mathrm{~g}$ of fertilizer was placed at the soil surface at the beginning of the experiment, $0.6 \mathrm{~g} 3$ weeks after sowing and $0.6 \mathrm{~g}$ on week 6 , when the first flowers were produced. From week 6 to week 12, $1 \mathrm{~g}$ of fertilizer was added every 2 weeks before watering. A total of $5.8 \mathrm{~g}$ of fertilizer was then added per pot. This corresponds to $48 \mathrm{~kg}$ of $\mathrm{N}$ and $\mathrm{K} ; 32 \mathrm{~kg}$ of P; $6.7 \mathrm{~kg}$ of S and $97 \mathrm{~kg}$ of Mg per hectare. Five replicates of each treatment combination, i.e. fertilization $\times$ soil type $\times \mathrm{LT} \times \mathrm{AC} \times$ plant species, were implemented.

\section{Sampling}

Plants were harvested on week 16. Shoot (leaves and stems) were cut at the soil surface and roots were separated from the soil by washing on a $600 \mu \mathrm{m}$ mesh. 
Root and shoot biomasses were dried at $60^{\circ} \mathrm{C}$ for $72 \mathrm{~h}$. Dried shoot and root biomasses were weighted. Because of differences in the timing of seed maturation between plant species, seeds were not harvested.

\section{Statistical analyses}

Data were analysed with ANOVAs using SAS GLM procedure (Sum of squares type III, SS3) (SAS 1990). A full model was first used to test all factors ("AC", "LT", "plant species", "fertilizer" and "soil") and all interactions between them (Table 1). When significant interactions between plant species and other factors (AC, LT, soil and fertilization) were detected, data were reanalysed separately for each plant species (Table 2) to describe in a more detailed way the effects of these treatments on each plant species. This allowed for example determining which plant species responded to which earthworm species and in which conditions (soil type and fertilization). Effects of treatments and interactions between treatments were tested on shoot biomass, root biomass, total biomass, and shoot/root ratio.

The residuals of each model were analysed to test for normality and homogeneity of variances. To determine the direction of significant effects, we used multiple comparison tests based of least square means taking into account Bonferroni's correction (LSmeans, LSmeans SAS statement). All tests were achieved with a significance level $\alpha=0.05$.

\section{Results}

In the present experiment, the main effects are due to the anecic earthworm species, L. terrestris. No significant effect of $A$. caliginosa was found. The full statistical model (Table 1) showed that L. terrestris
Table 1 ANOVA table of $F$-values for the effects of earthworms (AC and LT), soils, fertilizer and plant species on root, shoot and total biomass and shoot/root ratio $($ Total $\mathrm{df}=209)$

$*_{p}<0.05 ; * * p<0.01$;

$* * * p<0.001$

\begin{tabular}{|c|c|c|c|c|c|}
\hline & & Root biomass & Shoot biomass & Total biomass & Shoot/root \\
\hline & $\mathrm{df}$ & $\mathrm{F}$ & $\mathrm{F}$ & $\mathrm{F}$ & $\mathrm{F}$ \\
\hline $\mathrm{AC}$ & 1 & 0.63 & 2.72 & 1.83 & 2.90 \\
\hline LT & 1 & 0.30 & 0.03 & 0.07 & $6.63 *$ \\
\hline Soil & 1 & $4.30 *$ & $18.14 * * *$ & $12.17 * * *$ & $44.31 * * *$ \\
\hline Fertilizer & 1 & $42.92 * * *$ & $92.65 * * *$ & $55.68 * * *$ & $139.48 * * *$ \\
\hline Plant species & 2 & $199.22 * * *$ & $536.48 * * *$ & $609.26^{* * *}$ & $6.07 * *$ \\
\hline $\mathbf{A C} * \mathbf{L T}$ & 1 & 0.01 & 1.20 & 1.08 & 0.00 \\
\hline AC*soil & 1 & 3.14 & 0.11 & 0.03 & 0.03 \\
\hline AC ${ }^{*}$ Fertilizer & 1 & 1.48 & 0.00 & 0.06 & 0.10 \\
\hline$A C *$ plant species & 2 & 2.53 & 0.10 & 0.05 & 1.95 \\
\hline LT*soil & 1 & 0.11 & $4.02 *$ & $3.47 *$ & 0.00 \\
\hline LT*Fertilizer & 1 & 3.19 & $10.57 * * *$ & $11.46 * * *$ & $4.09 *$ \\
\hline LT*plant species & 2 & 0.90 & $4.56^{* *}$ & $4.45 * *$ & 0.01 \\
\hline Soil*plant species & 2 & $8.65 * * *$ & $17.34 * * *$ & $20.46 * * *$ & 1.10 \\
\hline Soil*Fertilizer & 1 & $10.70 * * *$ & $4.00 *$ & 1.26 & $42.48 * * *$ \\
\hline Fertilizer*plant species & 2 & $31.48 * * *$ & $27.74 * * *$ & $14.01 * * *$ & 0.94 \\
\hline AC*LT*soil & 1 & 0.11 & 0.08 & 0.11 & 0.57 \\
\hline AC* LT*plant species & 2 & 0.59 & 0.32 & 0.25 & $6.07 * * *$ \\
\hline AC* $\mathbf{L T}^{*}$ fertilizer & 1 & 0.10 & 0.99 & 1.00 & 0.43 \\
\hline LT*soil*fertilizer & 1 & 0.07 & 0.54 & 0.39 & 0.02 \\
\hline AC*soil*fertilizer & 1 & 0.40 & 1.00 & 0.62 & 0.98 \\
\hline plant species*soil*fertilizer & 2 & 1.07 & 0.78 & 1.07 & 1.26 \\
\hline AC*LT*soil*fertilizer & 1 & 0.15 & 0.56 & 0.61 & 0.42 \\
\hline AC*LT*plant species*fertilizer & 2 & 3.12 & $68.18 * * *$ & $72.46^{* * *}$ & $5.08 *$ \\
\hline $\mathbf{r}^{2}$ & & 0.79 & 0.90 & 0.89 & 0.62 \\
\hline
\end{tabular}


effect on shoot biomass and total biomasses varied with plant species (significant LT $\times$ plants species interaction, $p<0.01$ ), soil type (significant LT $\times$ soil interaction, $p<0.05$ ) and fertilizer (significant LT $\times$ fertilizer interaction, $p<0.001$ ). Its effects on the shoot/root ratio also varied with fertilizer addition (significant LT $\times$ fertilizer interaction, $p<0.05$ ). Further the presence of both earthworm species affected the shoot/root ratio and this effect varied with plant species (significant $\mathrm{AC} \times \mathrm{LT} \times$ plant species interaction, $p<0.001)$. Finally we found that the shoot/root and total biomasses were affected by the soil type and fertilizer but plant species differed in their responses (significant soil $\times$ plant species and fertilizer $\times$ plant species interactions, $p<0.001$ ). These general results and the significant interactions involving the plant species justify analysing separately for each plant species the effects of the presence of L. terrestris, soil type and fertilization (Table 2).

Shoot biomass

$L$. terrestris increased the shoot biomass of $T$. dubium $(+26 \%)$ but decreased the shoot biomass of $V$. persica $(-24 \%)$ (Table 2). Mineral fertilization increased the shoot biomasses of T. dubium, V. persica and P. annua (Table 2 ) by $24 \%, 46 \%$ and $48 \%$ respectively. The shoot biomass of $T$. dubium was $140 \%$ higher in the nutrient poor soil than in the nutrient rich one. The significant LT $\times$ fertilizer interaction for the shoot biomasses of $V$. persica and $P$. annua (Table 2) showed that effect of LT on these plants species varied with mineral fertilization. LT reduced the shoot biomasses of $V$. persica $(-37 \%)$ and $P$. annua $(-10 \%)$ when fertilizer was added (Fig. 1). The significant LT $\times$ Soil interaction, (Table 1 and LSmeans comparisons) indicated that the effect of LT on shoot biomass of $T$. dubium varied with soil type. It increased the shoot biomass of the legume $(+130 \%)$ only in the nutrient rich soil.

Root biomass

Mineral fertilization decreased the root biomasses of P. annua (-50\%) and T. dubium (-25\%). The root biomasses of the three plant species were affected by soil type with the highest root biomass in the nutrient rich soil for $P$. annua and $V$. persica while $T$. dubium 

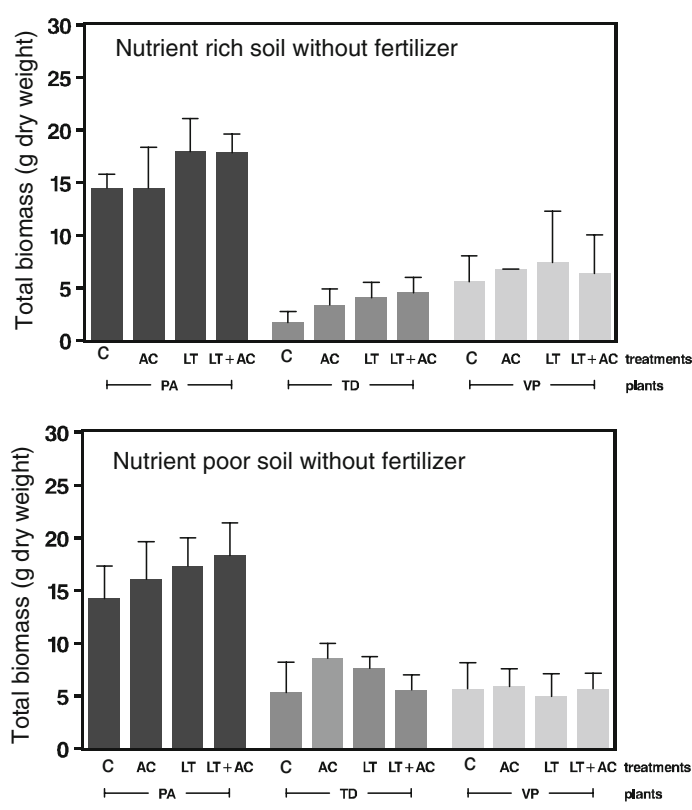

Fig. 1 Effects of earthworms, soil type and fertilizer on the total biomasses of $P$. annua (PA), T. dubium (TD) and $V$. persica (VP). Abbreviations: C, control treatment; AC, $A$.

showed higher root biomass in the nutrient poor soil (Table 2).

\section{Total biomass}

LT increased by $26 \%$ the total biomass of $T$. dubium but decreased the total biomass of $V$. persica by $24 \%$. Mineral fertilization increased the total biomass of $T$. dubium (16\%), P. annua (31\%) and V. persica (41\%) (Table 2). Significant interactions between LT and fertilizer were found for the total biomasses of $P$. annua and $V$. persica suggesting that effects of LT on these plant species varied with mineral fertilization (Table 2). Without mineral fertilization, LT increased the total biomass of $P$. annua $(+18 \%)$ while no significant effect of this earthworm was found when the fertilizer was added. For $V$. persica LT reduced $(-48 \%)$ the total biomass when the fertilizer was added but without mineral fertilization it did not show significant effect (significant LSmeans comparisons and Fig. 1). For T. dubium the significant LT $\times$ Soil interaction (Table 2) showed that the effect of LT on the total biomass of this plant species varied with soil type. In the nutrient rich soil the presence of LT increased significantly the total biomass of $T$. dubium $(+121 \%)$ while, no significant effect of LT was found in the nutrient poor soil (Fig. 1). Moreover, in the
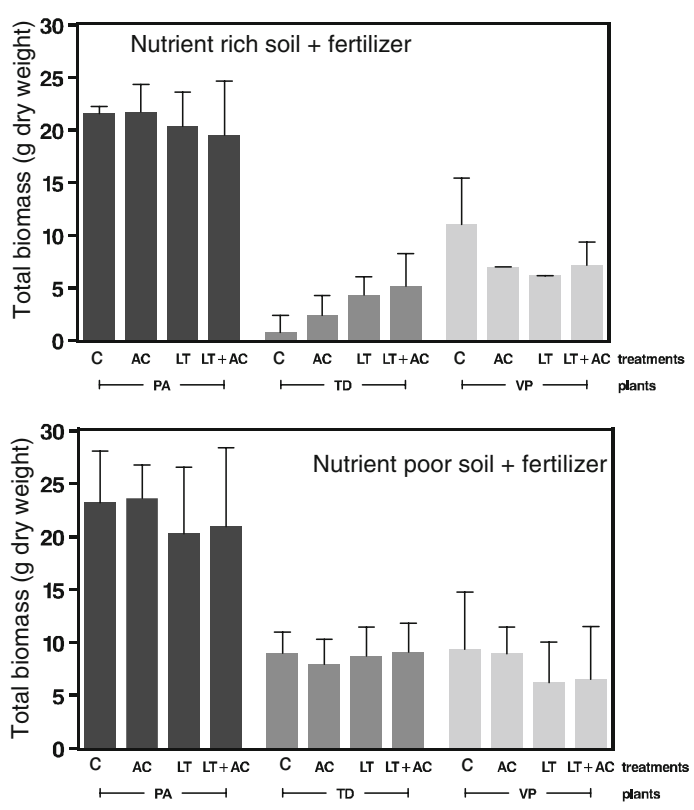

caliginosa only; LT, L. terrestris only; LT $+\mathrm{AC}$, combined treatment with $A$. caliginosa and $L$. terrestris

nutrient rich soil without earthworms, the mineral fertilization reduced $(-55 \%)$ the growth of the legume (Fig. 1). The effect of soil type on the total biomass of T. dubium varied with fertilizer addition (Table 2, significant Soil $\times$ Fertilizer interaction). In the nutrient poor soil, the addition of fertilizer increased $(+22 \%)$ the total biomass of the legume while no significant effect of fertilizer was found in the nutrient rich soil (Fig. 1).

\section{Shoo/root ratio}

The presence of LT increased by $21 \%$ the shoot/root ratio of $P$. annua. Shoot/root ratio of $V$. persica was increased $(+32 \%)$ when both earthworm species were present (Fig. 2 and LSmeans comparisons). Moreover the shoot/root ratios of the three plant species were significantly affected by the soil type and mineral fertilization. Their shoot/root ratios were higher in the nutrient poor soil than in the nutrient rich one (Fig. 2). Mineral fertilization increased the shoot/root ratio of T. dubium (193\%), V. persica (194\%) and P. annua (335\%). Effects of LT on the shoot/root ratio of $P$. annua varied with the soil type (significant LT $\times$ soil interaction, Table 2). LT increased (+27\%) the shoot/ root ratio of $P$. аnnua only in the nutrient poor soil (Fig. 2 and LSmeans comparisons). 

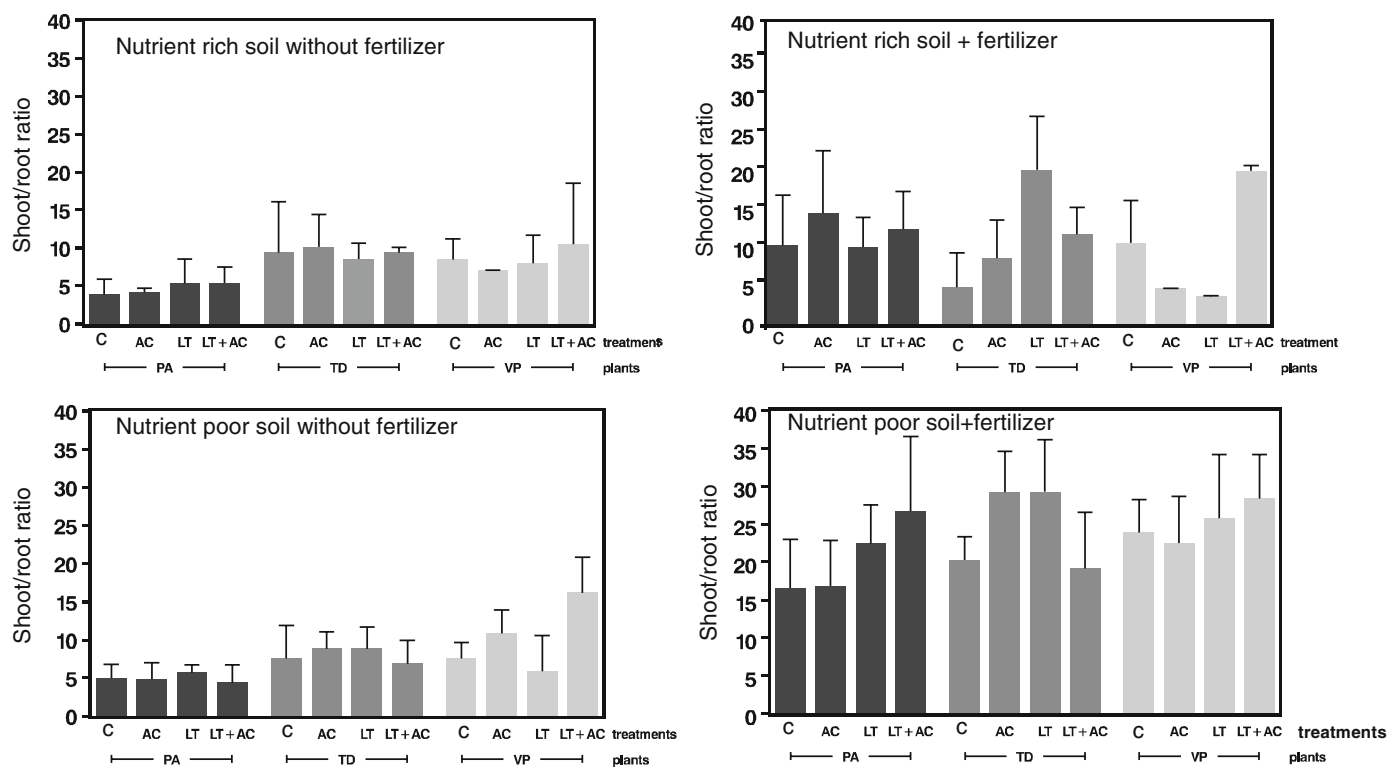

Fig. 2 Effects of earthworms, soil type and fertilizer on the shoot/root ratio of $P$. annua (PA), T. dubium (TD) and $V$. persica (VP). Abbreviations: C, control treatment; AC, $A$.

caliginosa only; LT, L. terrestris only; LT + AC, combined treatment with $A$. caliginosa and L. terrestris

\section{Discussion}

We hypothesized that: both earthworm species should affect (1) plant growth and (2) plant resource allocation only in the nutrient and organic matter poor soil; (3) significant interactive effects of the two earthworm species on plant growth and resource allocation should only be found in the nutrient and organic matter poor soil; (4) the impact of $A$. caliginosa and $L$. terrestris on plants should decrease with mineral fertilization.

It is generally thought that positive effects of earthworms on plant growth are more likely in nutrient poor soils than in nutrient rich soils (Brown et al. 2004). Although only L. terrestris showed significant effects, our results contradict this hypothesis. Our first hypothesis was not confirmed since LT, increased the shoot biomass and the total biomass of $T$. dubium only in the nutrient rich soil. Our second hypothesis was confirmed since there was no case where an earthworm species changed the shoot/root ratio in the rich soil but not in the poor soil. For example, for $P$. апnиa the presence of LT increased the shoot/root ratio but only in the poor soil as predicted. Few significant interactions between the anecic and the endogeic earthworms were found in this study, and these interactions did not depend on the soil type.

Consequently, our third hypothesis was not verified. Similarly, our fourth hypothesis was not supported by our results since there was no case where mineral fertilization decreased or suppressed a positive effect of an earthworm species on the growth of a plant species.

Plant growth

Effects of LT on the growth of T. dubium varied with the soil type but contrary to our expectation, this earthworm species did not have any significant effects on this plant in the nutrient poor soil. Indeed, LT increased the shoot and total biomasses of T. dubium only in the nutrient rich soil and mineral fertilization did not modify these effects (see Fig. 1). These results suggest that LT effect on T. dubium was probably not due to an enhancement of mineralization. This hypothesis is supported by the fact that the fertilizer addition had the opposite effect: it increased the total biomass of this plant only in the poor soil. These results should thus be explained by one of the four other mechanisms through which earthworms influence plant growth (Brown et al. 2004; Scheu 2003). A possible mechanism could be the production of growth regulators in the presence of LT (Blouin et al. 2006). Indeed, as microbial biomass is generally higher in clayey soils than in sandy soils (Hendrix 
et al. 1998), the activity of LT could have led to a greater production of phytohormones, through the stimulation of bacteria in the nutrient rich soil than in the nutrient poor soil and this resulted in an increase in the growth of T. dubium. Moreover, T. dubium, as a legume, is less sensitive to an increase in mineralization (Brown et al. 2004; Jenerette and Wu 2004), which further supports our rationale. An alternative explanation for the positive effect of LT on the legume is that this earthworm species could have increased microbial biomass burying organic matter in the soil which could in turn increase the immobilization of mineral nutrient (Van der Heijden et al. 2007) and allowed T. dubium to grow better because it is better adapted to nitrogen poor soils. This hypothesis is supported by the fact that the legume had a lower total biomass in the nutrient rich soil than in the nutrient poor one. Finally, the soil type itself did not affect the growth of $P$. annua and $V$. persica suggesting that these plant species are less sensitive to the soil quality than the legume.

Although LT increased the total biomass of $P$. аппиа without mineral fertilization, it decreased the total biomasses of $P$. annua and $V$. persica when mineral fertilizer was added. This suggests that, in our experiment, without mineral fertilization, LT affected these plants mostly through an increase in mineralization. An explanation for the negative effect of LT on the total biomass of $P$. annua and $V$. persica when mineral fertilizer was added is that this earthworm species could have enhanced the loss of added mineral nutrients through the galleries it produced. This suggests that LT could influence plant growth not only through mineralization of organic matter, at least when the soil contains enough organic matter, but also through its effects on nutrient losses (Barot et al. 2007; Dominguez et al. 2004).

\section{Shoot/root ratio}

The effect of earthworms on plant resource allocation is poorly documented and understood (Scheu 2003), but increase of the shoot/root ratio in the presence of earthworms has been documented before (Kreuzer et al. 2004; Scheu et al. 1999). In our study, LT effect on $P$. аппиа shoot/root ratio varied with the soil type, this earthworm species increased the shoot/root ratio only in the nutrient poor soil. The significant effect of the interaction between LT and the soil type on the shoot/root ratio is probably due to the strategies plants have evolved to optimize their resource allocation to their root system to efficiently take up nutrients. Indeed, when mineral nutrients are poorly available it is efficient for a plant to increase locally its root biomass in nutrient rich patches, while, if mineral nutrient availability is high enough in the whole soil, it is more efficient for a plant to decrease its total root biomass (Wilson 1988). However, plants have evolved different thresholds, first, in the local nutrient availabilities triggering local root proliferation, second, in the general nutrient availabilities triggering a change in the shoot/root ratio (Hutchings 1988). In this way, the observed variations of the responsiveness to earthworms of the shoot/root ratio with the soil type would reflect the scale and the precision at which root systems exploit the soil (Campbell et al. 1991). Moreover, the possible local release of plant growth factors (Muscolo et al. 1999) in earthworm casts and local changes in soil structure due to earthworm activities are also likely to influence local root densities as well as whole shoot/root ratios. This suggests that studying thoroughly changes in the allocation to the root system and in the root system architecture in the presence of earthworms and in different soils would provide useful information on root foraging strategies.

Interactive effect of both earthworm species on plant growth

Few significant effects of the interaction between LT and $\mathrm{AC}$ were found in our study; moreover the observed effects did not change with the soil type. This suggests that mechanisms through which the two earthworm species might influence plant growth do not interact. In our experiment this is also probably due to the fact that few significant effects of $A C$ were found. Contrarily to other experiments using similar biomass of AC (Kreuzer et al. 2004; Wurst et al. 2003, 2005), no significant effect of this earthworm species was found on plant growth in our study. AC individuals were probably less active than those of LT that produced a lot of casts on the soil surface (personal observations). Another complementary explanation is that AC might have enhanced mineralization or triggered the release of phytohormones in the soil without affecting significantly plant growth. 
In this case, AC might have influenced the physiology of these plants, for example the allocation of $\mathrm{N}$ to the root and aerial system, without affecting their biomass. This hypothesis is supported by the results of another experiment where $\mathrm{AC}$ affected the $\mathrm{N}$ content of plant without affecting their growth (Laossi et al. 2009). Other studies are needed to test for this kind of effect.

\section{Conclusion}

We have confirmed that earthworm effects (especially L. terrestris) on plants change with soil type (Doube et al. 1997) and nutrient supply. However, our results suggest that earthworm effects do not necessarily decrease with soil content in mineral nutrients and that earthworms do not affect plant via mineralization only. Consequently, other mechanisms are influential and new experiments are required to predict when and where the different mechanisms are influential. This is required to be able to predict how earthworm effects on plant growth vary with soil characteristics such as the availability of mineral nutrients, organic matter content and texture. The issue should be tackled by systematically comparing earthworm effect on plant, everything else being equal, in many different soils representing various combinations of these characteristics.

Acknowledgments We thank Abraham Bartolomé-Lasa, Anaïs Aubert and Ignace Kouassi Kouadio for help during the experiment. We thank Michael Bonkowski for helpful comments on the manuscript. This study was supported by the ANR program "jeune chercheur 2005" through the SolEcoEvo project, (JC05_52230).

\section{References}

Bardgett RD, Bowman WD, Kaufmann R, Schmidt SK (2005) A temporal approach to linking aboveground and belowground ecology. Trends Ecol Evol 20:634-641

Barot S, Ugolini A, Bakal Brikci F (2007) Nutrient cycling efficiency explains the long-term effect of ecosystem engineers on primary production. Funct Ecol 21:1-10

Blouin M, Barot S, Lavelle P (2006) Earthworms (Millsonia anomala, Megascolecidae) do not increase rice growth through enhanced nitrogen mineralization. Soil Biol Biochem 38:2063-2068

Brown GG, Barois I, Lavelle P (2000) Regulation of soil organic matter dynamics and microbial activity in the drilosphere and the role of interactions with other edaphic functional domains. Eur J Soil Biol 26:177-198

Brown GG, Edwards CA, Brussaard L (2004) How earthworms effect plant growth: burrowing into the mechanisms. In: Edwards CA (ed) Earthworm ecology, pp 13-49

Campbell BD, Grime JP, Mackey JML (1991) A trade-off between scale and precision in resource foraging. Oecologia 87:532-538

Dominguez J, Bohlen PJ, Parmelee RW (2004) Earthworms increase nitrogen leaching to greater soil depths in row crop agroecosystems. Ecosystems 7:672-685

Doube BM, Williams PML, Willmott PJ (1997) The influence of two species of earthworm (Aporrectodea trapezoides and Aporrectodea rosea) on the growth of wheat, barley and faba beans in three soil types in the greenhouse. Soil Biol Biochem 29:503-509

Edwards CA (2004) Earthworm ecology. CRC, Boca Raton, p 441

Edwards CA, Bohlen PJ (1996) Biology and ecology of earthworms, London

Hendrix PF, Petersona AC, Bearec MH, Coleman DC (1998) Long-term effects of earthworms on microbial biomass nitrogen in coarse and fine textured soils. Appl Soil Ecol 9:375-380

Hutchings MJ (1988) Differential foraging for resources and structural plasticity in plants. Trends Ecol Evol 3:200204

Jégou D, Cluzeau D, Balesdent J, Tréhen P (1998) Effects of four ecological categories of earthworms on carbon transfer in soil. Appl Soil Ecol 9:249-255

Jenerette GD, Wu J (2004) Interactions of ecosystem processes with spatial heterogeneity in the puzzle of nitrogen limitation. Oikos 107:273-282

Kreuzer K, Bonkowski M, Langel R, Scheu S (2004) Decomposer animals (Lumbricidae, Collembola) and organic matter distribution affect the performance of Lolium perenne (Poaceae) and Trifolium dubium (Fabaceae). Soil Biol Biochem 36:2005-2011

Laossi K-R et al. (2009) Effects of endogeic and anecic earthworms on the competition between four annual plants and their relative reproduction potential. Soil Biol Biochem (in press). doi:10.1016/j.soilbio.2009.05.009

Lavelle P, Spain A (2001) Soil ecology. Kluwer, Dordrecht, p 654

Lavelle P, Barois I, Blanchart E, Brown G, Brussaard L, Decaëns T, Fragoso C, Jimenez JJ, Kajondo KK, Martinez MDLA, Moreno A, Pashanasi B, Senapati B, Villenave C (1998) Earthworms as a resource in tropical agroesosystems. Nat resour 34:26-40

Muscolo A, Bovalo F, Gionfriddo F, Nardi S (1999) Earthworm humic matter produces auxin-like effects on Daucus carota cell growth and nitrate metabolism. Soil Biol Biochem 31:1303-1311

Partsch S, Milcu A, Scheu S (2006) Decomposers (Lumbricidae, collembola) affect plant performance in model grasslands of different diversity. Ecology 87:2548-2558

SAS (1990) GLM procedure. In: SAS/GRAPH software, version 6, volume 2. SAS Institute Inc., Cary

Scheu S (2003) Effects of earthworms on plant growth: patterns and perspectives. Pedobiologia 47:846-856 
Scheu S, Theenhaus A, Jones TH (1999) Links between the detritivore and the herbivore system: effects of earthworms and Collembola on plant growth and aphid development. Oecologia 119:541-551

Van der Heijden MGA, Bardgett RD, van Straalen NM (2007) The unseen majority: soil microbes as drivers of plant diversity and productivity in terrestrial ecosystem. Ecol Lett 11:1-15

Wilson JB (1988) A review of evidence on the control of shoot: root ratio, in relation to models. Ann Bot 61:433-449
Wurst S, Jones TH (2003) Indirect effects of earthworms (Aporrectodea caliginosa) on an above-ground tritrophic interaction. Pedobiologia 47:91-97

Wurst S, Langel R, Reineking A, Bonkowski M, Scheu S (2003) Effects of earthworms and organic litter distribution on plant performance and aphid reproduction. Oecologia 137:90-96

Wurst S, Langel R, Scheu S (2005) Do endogeic earthworms change plant competition? A microcosm study. Plant Soil 271:123-130 